\title{
In vitro and In vivo Effects of Deoxyribonucleic Acid Degradation Products on Virulent and Avirulent Group A Streptococci
}

\author{
By W. FIRSHEIN AND E. M. ZIMMERMAN \\ Department of Biology, Wesleyan University, Middletown, Connecticut, U.S.A.
}

(Received 31 January 1964)

SUMMARY

A deoxyribonuclease-treated deoxyribonucleic acid (DNase and DNA), further supplemented with all eight of the naturally occurring deoxynucleosides and deoxynucleotides enhanced the rate and extent of multiplication of several virulent strains of group A $\beta$-haemolytic streptococci (Streptococcus pyogenes) without affecting the multiplication of related avirulent strains. Ribonucleic acid (RNA) degradation products or yeast extract did not exert such selective effects. An enhancement of DNA synthesis occurred in suspensions of virulent strains augmented with the DNA degradation products, whereas avirulent strains did not respond. In addition, DNA synthesis was enhanced selectively in comparison to RNA and protein syntheses. The rate at which mice succumbed to infection by streptococci was enhanced considerably by the DNA degradation products, but the LD 50 remained unchanged.

\section{INTRODUCTION}

Several reports have cited the stimulatory effects of certain DNA degradation products on multiplication and virulence of pneumococci (Streptococcus pneumoniae) and staphylococci (Staphylococcus aureus) (Firshein \& Braun, 1958, 1960; McKee \& Braun, 1962). An interesting aspect of this work was the lack of any significant effects of the DNA degradation products on multiplication of avirulent variants of these organisms. With pneumococci, it was possible to correlate the growth-promoting effects of the DNA degradation products with a selective stimulation of DNA synthesis (Firshein, 1961a). The DNA degradation products which caused these effects consisted of deoxyribonuclease-treated DNA further supplemented with all eight of the naturally occurring deoxynucleosides and deoxynucleotides (hereafter called supplement-1). Ribonucleic acid derivatives were found to be inactive in stimulating multiplication of virulent pneumococci. Preliminary experiments with group A $\beta$-haemolytic streptococci showed that supplement-1 stimulated multiplication of virulent strains in a manner similar to that which occurred with pneumococci. The present report is concerned with the further elucidation of these observations, with a study of the effects of supplement-1 on multiplication of avirulent strains, and with the effects of the supplement in vivo.

\section{METHODS}

Organisms. All the strains of Streptococcus pyogenes used, except one avirulent strain, were obtained either from Dr S. S. Barkulis, or from the Hebrew University Hadassah Medical School, Jerusalem, Israel. One avirulent strain was freshly 
derived from its parental strain by picking smooth variant colonies which emerged after prolonged incubation of the parental strain on Difco brain heart infusion blood agar plates. Avirulence or virulence were ascertained by mouse infection in all cases. All strains showed $\beta$-haemolysis on blood agar, but only the virulent strains contained M protein, an important component of virulence in this group (Foley, Smith \& Wood, 1959; Wiley \& Wilson, 1961). The organisms were maintained on Difco brain heart infusion agar plates supplemented with $\mathbf{0 . 3} \%(\mathrm{w} / \mathrm{v})$ Difco neopeptone and $5 \%(\mathrm{v} / \mathrm{v})$ defibrinated sheep blood. Their designations follow :

Strain $\mathbf{M - 6}$ (virulent), strain $6 \mathrm{AM}^{-}$(avirulent, derived previously);

Strain M-18 (virulent), strain 18 $\mathrm{AM}^{-}$(avirulent, freshly isolated);

Strain $\mathbf{Q}-\mathbf{4 3 X}$ (virulent, derived by 43 mouse passages ofavirulent strain), strain Q-496 (avirulent).

Media for growth studies. In addition to the maintenance medium described above, brain heart infusion neopeptone broth supplemented with $0.5 \%(\mathrm{v} / \mathrm{v})$ defibrinated sheep blood was used routinely for growth studies. The medium was prepared double strength and diluted with the appropriate supplements dissolved in distilled water. In some experiments, Difco Todd-Hewitt broth supplemented with $0.5 \%(v / v)$ defibrinated sheep blood was used. Lastly, a medium containing casitone, tryptone, yeast extract (all Difco), and albumin (Fraction $\mathrm{V}$ from bovine serum albumin, Armour and Co.; Marmur \& Hotchkiss, 1955) was prepared for growth studies and for obtaining large numbers of viable organisms for suspension studies.

Growth studies. Viable counts were made by the serial dilution method and checked by direct microscopic counts. Since virulent and avirulent streptococci form chains and clump in growth media, errors in determining the actual number of viable cocci may occur. These errors can be minimized by vigorous mixing of the dilution tubes before plating. However, the relative viable counts of virulent and avirulent streptococci in response to the supplement were considered to be the important point. Therefore, it was examined whether the supplement affected the number of chains and the number of cocci per chain. It was found that the added supplements had no effects on these variables.

Preparation of DNA, DNase-treated DNA and other substances. Highly polymerized calf-thymus Na-DNA was prepared by the method of Kay, Simmons \& Dounce (1952). Deoxyribonuclease-treated DNA, deoxynucleosides and deoxynucleotides were prepared as described previously (Firshein, 1961 $a$ ). Concentrations used for all strains were as follows: ( $\mu \mathrm{g} . / \mathrm{ml}$. medium), DNA, 130; deoxyribonuclease, 25; deoxynucleosides, 800 (200 each of deoxyadenosine, deoxyguanosine, deoxycytidine, thymidine); deoxynucleotides, 200 each of the phosphorylated deoxynucleosides. Ribonuclease-treated RNA, nucleosides and nucleotides were prepared in the same manner and used in the same concentrations as the DNA degradation products, except that $\mathrm{Mg}^{2+}$ was omitted in the preparation of ribonuclease-treated RNA.

Suspension studies, extraction and measurement of nucleic acids and protein. The methods used were as described previously (Firshein, 1961 a). The analyses were accurate to within $3 \%$ for protein (Lowry, Rosebrough, Farr \& Randall, 1951), and $5 \%$ for DNA and RNA (Brody, 1953; Drury, 1948, respectively). Percentage 
increase of DNA over protein was determined in the following way. For a given measurement, an amount of DNA (in $\mu \mathrm{g} . / \mathrm{ml}$.) was calculated whose $\%$ increase over zero time was identical with that observed for the \% increase in protein over zero time. This calculated amount was compared to the actual amount of DNA obtained experimentally. When the latter figure was higher, the $\%$ increase of the actual value was determined over the calculated value.

Manometric experiments. The Warburg apparatus was used with $20 \%(\mathrm{w} / \mathrm{v})$ KOH in the centre well. Supplement- 1 and glucose were added to the sidearms and organisms (in $0.02 \mathrm{M} \mathrm{Na}-\mathrm{K}$ phosphate buffer, $\mathrm{pH} \mathrm{7.5)} \mathrm{were} \mathrm{added} \mathrm{to} \mathrm{the} \mathrm{centre}$ compartment of the Warburg flask. To prevent toxic effects of $\mathrm{H}_{2} \mathrm{O}_{2}$ accumulation, catalase (Nutritional Biochemicals) was added to $0.005 \%$ (w/v). Manometers were tipped $10 \mathrm{~min}$. after equilibration of the flasks at $37^{\circ}$.

Animal experiments. Albino Swiss mice weighing about $18 \mathrm{~g}$. were injected intraperitoneally with dilutions (in $0.9 \%$ saline) of organisms of the different strains, at the same time as intraperitoneal injection of supplement-1. Ten mice were used per dilution of infecting organism. The total concentration of supplement-1 injected into each animal was identical with that used in culture media $1.73 \mathrm{mg} . / \mathrm{ml}$. Injection of twice the usual amount of supplement-1 without streptococcal infection did not affect the mice in any observed manner.

\section{RESULTS}

\section{Effects of supplement-1 on multiplication}

Initial experiments were concerned with the effects of supplement-1 on multiplication of the various virulent and avirulent strains in brain heart infusion neopeptone blood broth. The concentrations chosen for the various experiments corresponded with those found to exhibit optimum responses in pneumococcal cultures (Firshein \& Braun, 1960). It was observed (Figs. 1-3) that the virulent and avirulent strains showed strikingly dissimilar responses to the supplement. The supplement stimulated the rate and extent of multiplication of virulent strains, but had no significant effects on proliferation of avirulent strains. After $12 \mathrm{hr}$, the enhancement for virulent strains with respect to final yield of viable organisms was 11 -fold for strain $\mathbf{Q}-\mathbf{4 3 x}$, 15-fold for strain M-18, and 9-fold for strain $\mathrm{M-6}$. The DNase-treated DNA (DNA digest) accounted for a substantial portion of the stimulation with all three virulent strains, despite its low concentration in the supplement ( $8 \%, \mathrm{w} / \mathrm{w}$, see 'Methods'). Deoxynucleosides and deoxynucleotides augmented this response; by themselves, they produced only a small enhancement.

The rate of multiplication of virulent strains was also increased from control rates in the presence of the supplement, as evidenced by decreases in the generation time. The generation time was decreased from 55 to $37 \mathrm{~min}$. for strain $\mathrm{Q}-43 \mathrm{x}$, from 70 to $38 \mathrm{~min}$. for strain $\mathrm{M}-18$, and from 100 to $61 \mathrm{~min}$. for strain $\mathrm{M}-6$.

Table 1 demonstrates that the selective effects of supplement-1 on the multiplication of the virulent strains were not restricted to brain heart infusion neopeptone blood broth, but occurred in other media that supported growth of the streptococci. Only the results obtained with two pairs of virulent and avirulent strains are shown, the third pair acted in the same manner.

With a pair of virulent and avirulent strains, the maximum stimulation of multiplication of virulent organisms by supplement-1 occurred at a concentration of 
$1200 \mu \mathrm{g} . / \mathrm{ml}$. (Fig. 4). Avirulent organisms did not respond to any concentration of supplement-1.

Table 1. Effects of DNA degradation products on multiplication of Group $A$ streptococci in different media

Procedures are described in the Methods. Inocula $\left(\times 10^{-5}\right)$ : strain Q-43x, 9; strain Q-496, $12 \cdot 5$; strain $\mathrm{M}-18,8$; strain $18 \mathrm{AM}^{-}, 9 \cdot 5$.

\begin{tabular}{|c|c|c|c|c|}
\hline \multirow[b]{2}{*}{ Medium } & \multirow[b]{2}{*}{ Strain of organism } & \multicolumn{2}{|c|}{ Additions } & \multirow{2}{*}{$\begin{array}{l}\text { Viable count } \\
\text { after } 12 \mathrm{hr} \\
\left(\times 10^{5}\right)\end{array}$} \\
\hline & & Supplement-1 & Control & \\
\hline \multirow{4}{*}{$\begin{array}{l}\text { Difco Todd-Hewitt broth } \\
+0.5 \%(v / v) \text { defibrinated } \\
\text { sheep blood }\end{array}$} & Q-43x (virulent) & + & - & 11,000 \\
\hline & & - & + & 405 \\
\hline & Q-496 (avirulent) & + & - & 600 \\
\hline & & - & + & 580 \\
\hline \multirow{4}{*}{$\begin{array}{l}\text { CAT medium (Marmur \& } \\
\text { Hotchkiss, 1955) }\end{array}$} & $Q-43 x$ & + & - & 8,500 \\
\hline & & - & + & 400 \\
\hline & $Q-496$ & + & - & 1,000 \\
\hline & & - & + & 800 \\
\hline \multirow{4}{*}{$\begin{array}{l}\text { Difco Todd-Hewitt broth } \\
+0.5 \%(v / v) \text { defibrinated } \\
\text { sheep blood }\end{array}$} & M-18 (virulent) & + & - & 3,200 \\
\hline & & - & + & 310 \\
\hline & $18 \mathrm{AM}^{-}$(avirulent) & + & - & 900 \\
\hline & & - & + & 1,050 \\
\hline \multirow[t]{4}{*}{ CAT medium } & M-18 & + & - & 905 \\
\hline & & - & + & 150 \\
\hline & $18 \mathrm{AM}^{-}$ & + & - & 670 \\
\hline & & - & + & 900 \\
\hline
\end{tabular}

Effects of supplement-1 in vivo

McKee \& Braun (1962) and Firshein \& Braun (1958) observed that the DNA degradation-products enhanced the infectivity of virulent staphylococci and pneumococci for mice. Therefore, it appeared of interest to ascertain whether such products would also influence the course of a streptococcal infection. Two of the strains containing $M$ protein (strains $M-18, Q-43 x$ ) were used to infect mice and the mice were treated immediately after infection with supplement-1 as described under Methods. The results (Table 2) show that supplement-1 enhanced the rate at which mice succumbed, but the LD 50 dose was not decreased significantly. The ET 50 dose was calculated for one strain (M-18) using Litchfield's nomographs (Litchfield, 1949). Figure 5 shows a clear difference between controls and treated animals, with the ET $5039 \mathrm{hr}$ for the controls and only $25 \cdot 2 \mathrm{hr}$ for the treated animals.

Effects of supplement-1 on nucleic acid and protein syntheses in suspensions of cocci

Firshein $(1961 a)$ found that the selective enhancement of multiplication of virulent strains of pneumococci in medium containing supplement-1 involved an effect on DNA metabolism. It was of interest, therefore, to test the effects of the supplement on DNA synthesis in streptococci. As in the experiments with pneumococci, measurements of DNA were made in suspensions of streptococci (Firshein, $1961 a$ ) in the presence of supplement-1 or its component parts (the DNA digest 
alone, and mixtures of deoxynucleosides and deoxynucleotides by themselves). RNA and protein syntheses were also estimated. The results of these experiments, replicated several times (Table 3), showed that DNA synthesis was enhanced selectively in comparison to RNA and protein syntheses in suspensions of virulent streptococci containing supplement-1. In contrast, suspensions of avirulent streptococci showed no response to the supplement. Tests with parts of the supplement

Table 2. Effects of supplement-1 on the survival of mice infected with group $\boldsymbol{A}$ streptococci

Procedures are described in the Methods. See Fig. 5 for a further analysis of the effects of supplement-1 in vivo.

\begin{tabular}{|c|c|c|c|c|c|c|c|c|c|c|c|c|}
\hline \multirow{2}{*}{ Treatment } & \multirow{2}{*}{$\begin{array}{c}\text { Strain } \\
\text { of } \\
\text { organism }\end{array}$} & \multirow{2}{*}{$\begin{array}{c}\text { No. of } \\
\text { infecting } \\
\text { organisms }\end{array}$} & \multicolumn{10}{|c|}{ Time (hr) of observation } \\
\hline & & & \multicolumn{10}{|c|}{ Cumulative $\%$ mortality } \\
\hline $\begin{array}{l}\text { Supplement-1 } \\
\text { dissolved in } \\
0.9 \%(w / v) \\
\text { saline }\end{array}$ & M-18 & $\begin{array}{l}10^{2} \\
10^{3} \\
10^{4}\end{array}$ & $\begin{array}{r}0 \\
0 \\
10\end{array}$ & $\begin{array}{r}0 \\
0 \\
50\end{array}$ & $\begin{array}{r}0 \\
20 \\
60\end{array}$ & $\begin{array}{r}0 \\
30 \\
100\end{array}$ & $\begin{array}{l}10 \\
30 \\
\rightarrow\end{array}$ & $\overrightarrow{40}$ & $\rightarrow$ & & & \\
\hline $\begin{array}{l}0.9 \%(w / v) \\
\text { saline }\end{array}$ & M-18 & $\begin{array}{l}10^{2} \\
10^{3} \\
10^{4}\end{array}$ & $\begin{array}{l}0 \\
0 \\
0\end{array}$ & $\begin{array}{r}0 \\
0 \\
20\end{array}$ & $\begin{array}{r}0 \\
0 \\
20\end{array}$ & $\begin{array}{r}\mathbf{0} \\
\mathbf{0} \\
\mathbf{3 0}\end{array}$ & $\begin{array}{r}0 \\
0 \\
30\end{array}$ & $\begin{array}{r}0 \\
10 \\
30\end{array}$ & $\begin{array}{r}0 \\
10 \\
60\end{array}$ & $\begin{array}{l}10 \\
20 \\
90\end{array}$ & $\begin{array}{r}\overrightarrow{30} \\
100\end{array}$ & $\vec{\rightarrow}$ \\
\hline $\begin{array}{l}\text { Supplement-1 } \\
\text { dissolved in } \\
0.9 \%(w / v) \\
\text { saline }\end{array}$ & $Q-43 x$ & $\begin{array}{l}10^{1 \cdot 5} \\
10^{2 \cdot 5} \\
10^{8 \cdot 5}\end{array}$ & $\begin{array}{r}0 \\
0 \\
20\end{array}$ & $\begin{array}{r}0 \\
20 \\
70\end{array}$ & $\begin{array}{r}0 \\
40 \\
100\end{array}$ & $\begin{array}{l}10 \\
40 \\
\rightarrow\end{array}$ & $\begin{array}{l}20 \\
70\end{array}$ & $\begin{array}{l}40 \\
80\end{array}$ & $\vec{\rightarrow}$ & & & \\
\hline $\begin{array}{l}0.9 \%(w / v) \\
\text { saline }\end{array}$ & $Q-43 x$ & $\begin{array}{l}10^{1 \cdot 5} \\
10^{2 \cdot 5} \\
10^{3 \cdot 5}\end{array}$ & $\begin{array}{l}\mathbf{0} \\
\mathbf{0} \\
\mathbf{0}\end{array}$ & $\begin{array}{l}0 \\
0 \\
0\end{array}$ & $\begin{array}{r}0 \\
0 \\
20\end{array}$ & $\begin{array}{r}\mathbf{0} \\
\mathbf{0} \\
\mathbf{3 0}\end{array}$ & $\begin{array}{l}10 \\
30 \\
60\end{array}$ & $\begin{array}{l}20 \\
40 \\
70\end{array}$ & $\begin{array}{r}\overrightarrow{40} \\
100\end{array}$ & $\stackrel{40}{\rightarrow}$ & 60 & $90 \rightarrow$ \\
\hline
\end{tabular}

Table 3. Effects of DNA degradation products on nucleic acid and protein syntheses by group $A$ streptococci

Procedures are described in the Methods

\begin{tabular}{|c|c|c|c|c|c|c|}
\hline \multirow{2}{*}{$\begin{array}{c}\text { Strain } \\
\text { of } \\
\text { organism }\end{array}$} & \multicolumn{2}{|c|}{ Additions } & \multicolumn{3}{|c|}{$\begin{array}{l}\text { Increase (\%) over } \\
\text { zero time after 70 min. }\end{array}$} & \multirow{2}{*}{$\begin{array}{l}\text { Increase (\%) } \\
\text { of DNA over } \\
\text { protein }\end{array}$} \\
\hline & DNA + DNase & $\begin{array}{c}\text { Deoxynucleosides }+ \\
\text { deoxynucleotides }\end{array}$ & DNA & RNA & Protein & \\
\hline \multirow[t]{4}{*}{ Q-43X (virulent) } & - & - & 65 & 60 & 70 & . \\
\hline & + & + & 150 & 78 & 80 & 50 \\
\hline & + & - & 115 & 74 & 65 & 33 \\
\hline & - & + & 87 & 70 & 70 & 13 \\
\hline \multirow{4}{*}{ Q-496 (avirulent) } & - & - & 78 & 76 & 80 & • \\
\hline & + & + & 85 & 90 & 81 & 2 \\
\hline & + & - & 85 & 75 & 75 & 3 \\
\hline & - & + & 65 & 73 & 70 & . \\
\hline \multirow[t]{4}{*}{ M-6 (virulent) } & - & - & 20 & 20 & 19 & . \\
\hline & + & + & 70 & 25 & 25 & 36 \\
\hline & + & - & 52 & 26 & 24 & 22 \\
\hline & - & + & $\mathbf{3 8}$ & 23 & 22 & 12 \\
\hline \multirow[t]{4}{*}{$6 \mathrm{AM}^{-}$(avirulent) } & - & - & 31 & 28 & 30 . & . \\
\hline & + & + & 28 & 31 & $\mathbf{3 3}$ & . \\
\hline & + & - & $\mathbf{3 0}$ & 33 & 28 & 1 \\
\hline & - & + & 25 & 25 & 27 & . \\
\hline I6 & & & & & G. Mi & crob. $\mathrm{xxxvy}$ \\
\hline
\end{tabular}


revealed that the DNA digest stimulated DNA synthesis selectively to a greater extent than did mixtures of deoxynucleosides and deoxynucleotides, thus paralleling their effects in growing cultures with respect to enhancement of multiplication of virulent strains (see Figs. 1-3).

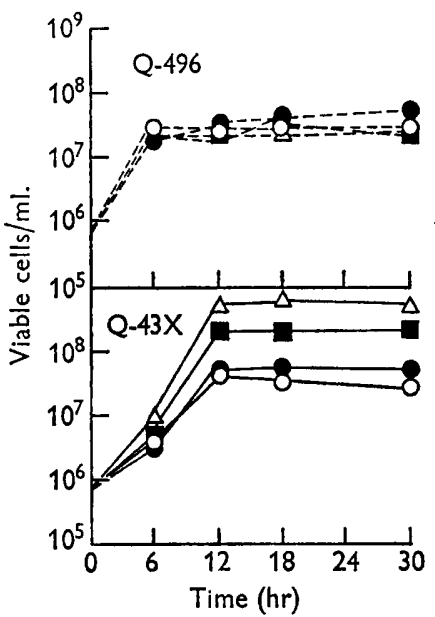

Fig. 1

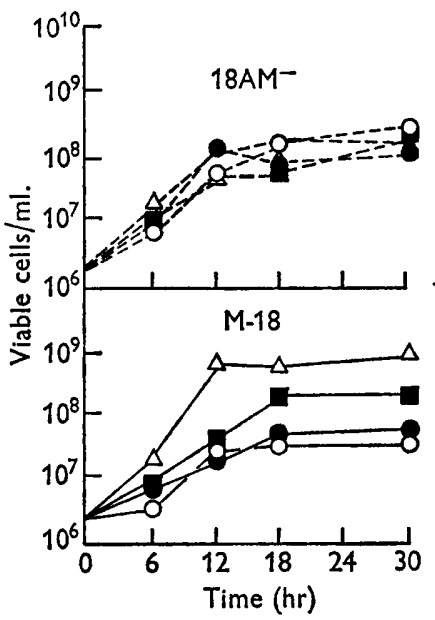

Fig. 2

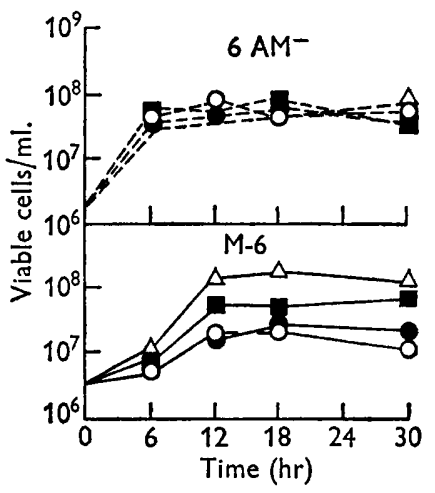

Fig. 3

Figs. 1-3. Viable counts of virulent and avirulent strains of Group A streptococci in the presence or absence of supplement-1. For concentrations of supplement-1 and its moieties, see Methods. Medium was brain heart infusion neopeptone blood broth. Virulent: solid line; avirulent, broken line. Supplement-1 $(\triangle)$; DNA + deoxyribonuclease ( $\square$ ); deoxynucleosides + deoxynucleotides $(O) ; \operatorname{control}(O)$.

Table 4. Effects of $R N A$ degradation products and yeast extract on multiplication and DNA synthesis of group $A$ streptococci

Procedures are described in the Methods. Concentration of yeast extract (Difco) in suspending or in culture medium was $0 \cdot 3 \%(\mathrm{w} / \mathrm{v})$. Medium for viable count determinations was brain heart infusion neopeptone blood broth. Inocula for culture medium were as follows $\left(\times 10^{5}\right)$ : strain $\mathrm{M}-18,9$; strain $18 \mathrm{AM}^{-}, 10$; strain $\mathrm{M}-6,13$; strain $6 \mathbf{A M}^{-}, 16$.

\section{Additions}

RNA derivatives

Yeast extract

Supplement-1

None

RNA derivatives

Yeast extract

Supplement-1

None

RNA derivatives

Yeast extract

Supplement-1

None

RNA derivatives

Yeast extract

Supplement-1

None
Viable count

after $12 \mathrm{hr}$ in complete medium $\left(\times 10^{5}\right)$

$$
\begin{array}{r}
\mathbf{5 2 5} \\
1200 \\
2000 \\
400 \\
3500 \\
8000 \\
3100 \\
2200 \\
300 \\
950 \\
1100 \\
190 \\
1000 \\
1800 \\
900 \\
1300
\end{array}
$$

Increase (\%) of DNA over protein in suspensions

(avirulent)

$$
\begin{array}{r}
1 \\
1 \\
40 \\
\cdot \\
\cdot \\
2 \\
\cdot \\
\cdot \\
\cdot \\
2 \\
32 \\
1 \\
4 \\
3 \\
\cdot \\
\cdot
\end{array}
$$




\section{Effects of other nutrients on DNA synthesis and multiplication}

It may be argued that the supplement contained components which affected the overall metabolic rate in virulent streptococci, and that no specific effects were being observed. Table 4 summarizes the effects of yeast extract and RNA degradation products on DNA synthesis and multiplication of virulent and avirulent strains. In no instance were effects similar to those elicited by the DNA degradation products

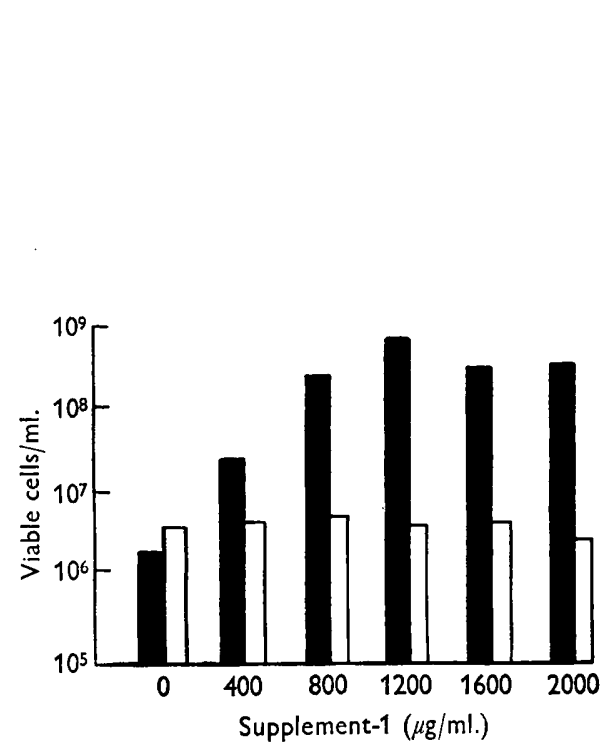

Fig. 4

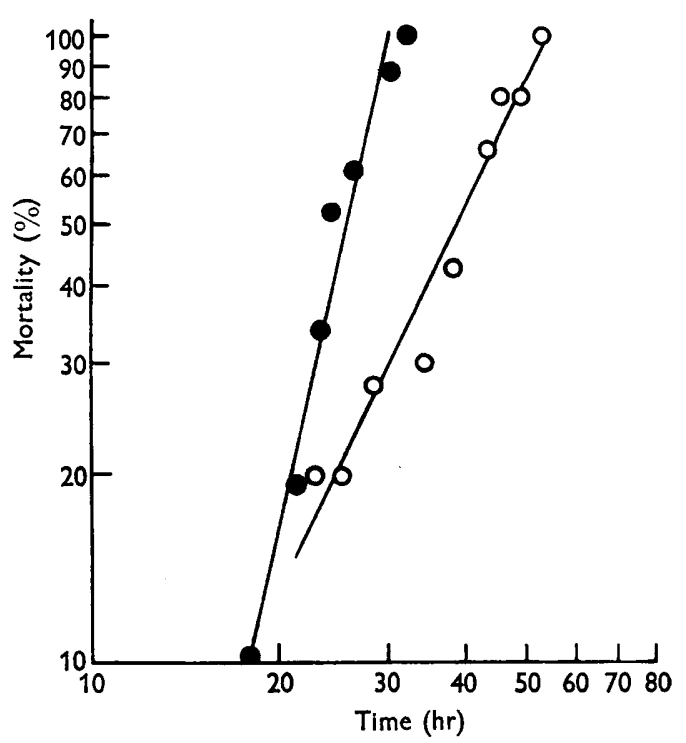

Fig. 5

Fig. 4. Effects of concentration of supplement-1 on the number of viable organisms of a virulent and avirulent strain of Group A streptococci after incubation for $12 \mathrm{hr}$. Medium was brain heart infusion neopeptone blood broth. Initial inocula : $\left(\times 10^{4}\right)$, virulent (strain Q-43X), 6 ; avirulent (strain Q-496), 10. Shaded bars, virulent; unshaded bars, avirulent.

Fig. 5. Cumulative \% mortality of mice as a function of time, plotted on log probability paper for strain $\mathrm{M}-18$. Forty mice/group, $10^{4}$ organisms injected into each animal. Conditions of treatment, inoculation of organisms, concentration of supplement-1 were as described in Methods. The confidence limits for the ET50 (median effective time) with a 19/20 probability found by using Litchfield's nomographs (Litchfield, 1949) were as follows: ET50 for treated was $25 \cdot 2 \mathrm{hr}(26 \cdot 7-23 \cdot 7)$. The slope of the line was 1.21 (1.26-1·15). ET50 for control was $39 \mathrm{hr}(44 \cdot 4-34 \cdot 2)$. The slope of the line was $1.54(1 \cdot 69-1 \cdot 53)$. (O), mice treated with supplement-1 at time of infection with strain $M-18$; $(0)$, infected with strain M-18 only.

obtained. Yeast extract stimulated multiplication of avirulent and virulent streptococci in complete medium to approximately the same extent, and had no effects on DNA synthesis in coccal suspensions. The RNA degradation products were almost without effect on multiplication or DNA synthesis of virulent and avirulent strains.

\section{Effects of supplement-1 on respiration}

The ability of supplement-1 to enhance respiration of pneumococci (Firshein, $1961 b, 1962)$, and the importance of such effects in the enhancement of DNA synthesis and multiplication in this organism, suggested a study of the effects of 
supplement-1 on respiration of streptococci. It was found (Fig. 6) that the supplement did not enhance oxygen uptake in glucose-containing suspensions of virulent streptococci. However, the supplement was oxidized extensively in the absence of glucose in suspensions of virulent organisms. With avirulent organisms, oxygen uptake was depressed in suspensions containing glucose and supplement-1, as compared with suspensions containing glucose only. Avirulent streptococci were also capable of oxidizing supplement- 1 in the absence of glucose, but the values obtained were not as high as those with virulent organisms.
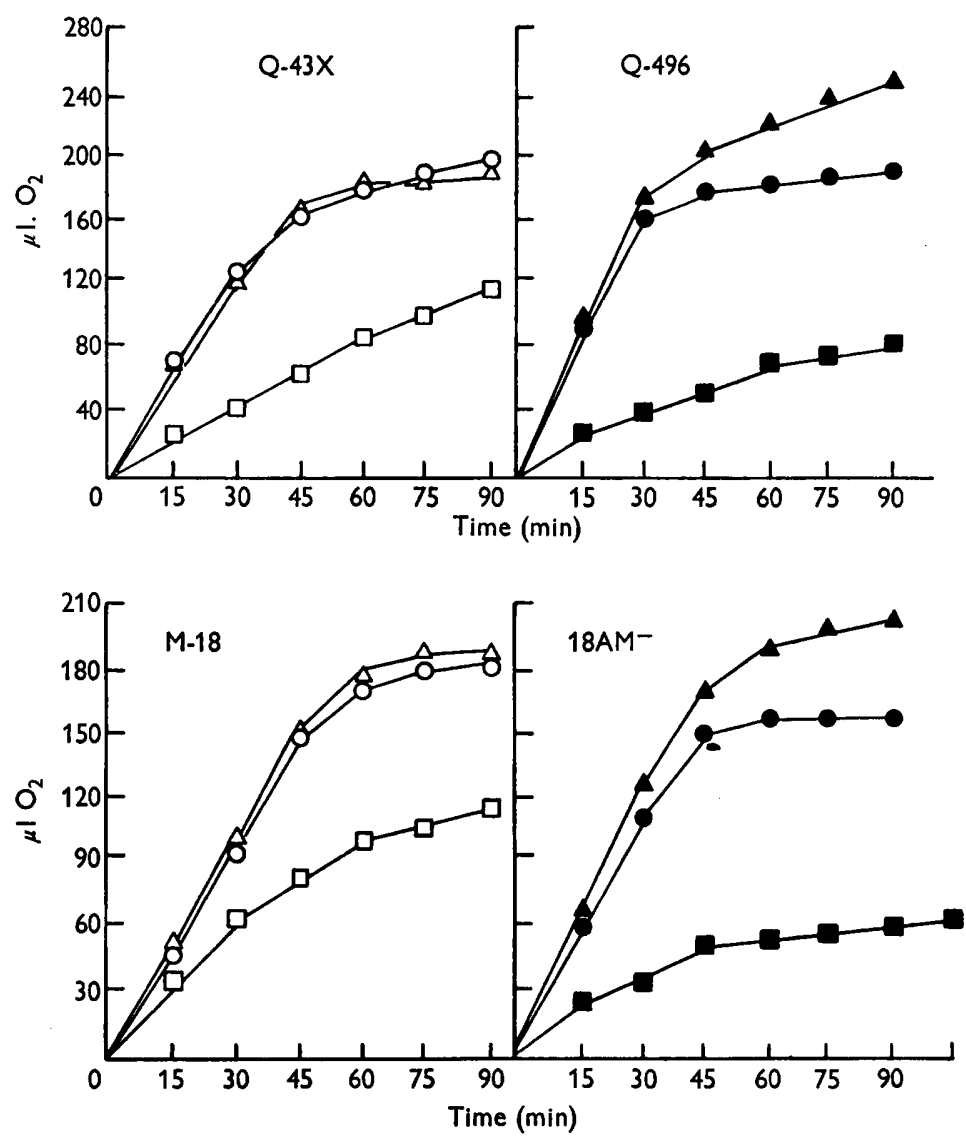

Fig. 6. Effects of supplement-1 on oxygen uptake of virulent and avirulent strains of group A streptococci in suspensions containing glucose. For concentration of supplement-1 see Methods. Concentration of glucose was the same as that in washed suspensions of cocci $(50 \mu \mathrm{M})$. Endogenous rates are not shown, they were negligible for all strains tested. $(O),(O)$, supplement-1 + glucose;( $\square)(\square)$, supplement-1 alone; $\triangle$ )( $(\Delta)$, glucose. Inocula for all strains were adjusted to the same value, $8.5 \times 10^{8}$ viable cocci $/ \mathrm{ml}$.

\section{DISCUSSION}

To some extent, the interest of the results described in the paper (Firshein \& Zimmerman, 1964) concerning $\mathrm{Mn}^{2+}$ lies in the contrast between them and those described in the present paper. It is convenient to discuss the findings of both papers here. 
The observations made with DNA degradation products extend the generality of the selective effects of such products on multiplication and DNA synthesis of virulent strains of Gram-positive pathogenic cocci. The similarities can be summarized conveniently in Table 5.

Table 5

\begin{tabular}{|c|c|c|c|c|c|}
\hline & \multicolumn{4}{|c|}{ Addition of supplement-1 } & \\
\hline Organism & $\begin{array}{c}\text { Stimulation of } \\
\text { multiplication } \\
\text { of virulent } \\
\text { strains }\end{array}$ & $\begin{array}{l}\text { Effects } \\
\text { on } \\
\text { avirulent } \\
\text { strains }\end{array}$ & $\begin{array}{c}\text { Stimulation } \\
\text { of } \\
\text { infectivity }\end{array}$ & $\begin{array}{l}\text { Stimulation of } \\
\text { DNA synthesis } \\
\text { by virulent } \\
\text { strains }\end{array}$ & References \\
\hline Pneumococci & + & - & + & + & $\begin{array}{l}\text { Firshein \& Braun } \\
(\mathbf{1 9 5 8 )}, \text { Firshein } \\
(1961 a)\end{array}$ \\
\hline Staphylococci & + & - & + & $?$ & $\begin{array}{l}\text { McKee \& Braun } \\
\quad(1962)\end{array}$ \\
\hline Streptococci & + & - & + & + & - \\
\hline
\end{tabular}

The results described in the previous paper (Firshein \& Zimmerman, 1964) concerning $\mathrm{Mn}^{2+}$ suggest that the effects of $\mathrm{Mn}^{2+}$ and DNA degradation products on multiplication of pneumococci (Firshein, 1962) and streptococci may be different. Some question had arisen previously with pneumococci because both augmentations stimulated the multiplication of virulent strains. However, DNA degradation products have now been shown to act in the same manner in pneumococci and streptococci, whereas $\mathrm{Mn}^{2+}$ acts differently in these two species. Actually, the results obtained with virulent pneumococci and $\mathrm{Mn}^{2+}$ may be unique, since effects of $\mathrm{Mn}^{2+}$ on multiplication of avirulent pneumococci (Firshein, 1962) and staphylococci (Ramsey \& Wilson, 1957) have also been found to be inhibitory. An interesting point in the present studies with streptococci is that both $\mathrm{Mn}^{2+}$ and the DNA degradation products exert their effects selectively on virulent and avirulent strains. However, the effects of the former are inhibitory with respect to multiplication, while the effects of the latter are stimulatory.

As with pneumococci (Firshein, $1961 a$ ), it appears that the stimulation of multiplication of virulent streptococci by DNA degradation products is associated with increased rates of DNA synthesis. This is supported by the observation that the effects of components of supplement-1 on DNA synthesis closely parallel their effects on multiplication. The greater the enhancement of DNA synthesis by moieties of the supplement in suspensions of cocci, the greater the stimulation of multiplication.

Although DNA synthesis may represent the primary process affected by the degradation products in streptococci and pneumococci, some important secondary effects of the products on respiration may differ in both species. For example, with pneumococci (Firshein, 1961 b) components of supplement-1 stimulate the oxidation of glucose by virulent strains. This stimulation provides excess energy needed for incorporation of deoxynucleosides and deoxynucleotides, and enhanced DNA synthesis. The supplement itself is not oxidized significantly by virulent pneumococci. In contrast, with streptococci the supplement is oxidized extensively by 
virulent strains, and it is incapable of stimulating the oxidation of glucose. In fact, a slight depression of oxygen uptake occurs when the supplement and glucose are present together in suspensions of streptococci, in comparison to glucose alone. Thus, no excess energy is available to the virulent organisms. However, the fact that enhanced DNA synthesis does occur in suspensions under these conditions shows that: (1) the available energy is sufficient for metabolizing the DNA degradation products; and (2) enough of the supplement remains unoxidized for synthetic purposes, in spite of the oxidation of the degradation products.

Oxygen uptake is inhibited to a greater extent in suspensions of avirulent streptococci containing glucose and DNA degradation products than in suspensions of virulent streptococci containing such supplements. This sensitivity in both types of organisms may involve the lack of sufficient enzymic raw material to oxidize both supplement-1 and glucose when these are present together. The depression of oxygen uptake would result from the fact that a proportion of the available oxidativeenzyme supply normally used in glucose oxidation would be used to act on substrates (supplement-1) which were not as efficiently oxidized. If this hypothesis be valid, then the pool of oxidative enzymes in avirulent streptococci may be less than that found in virulent strains. Experiments with cell-free extracts are now under way to examine this possibility.

$\mathrm{Mn}^{2+}$ appears to exert its inhibitory effects differently in virulent and avirulent streptococci. In suspensions of virulent streptococci a general depression of respiration, nucleic acid synthesis and protein synthesis occurs, whereas in suspensions of avirulent streptococci, a selective inhibition of nucleic acid synthesis is observed. Protein synthesis is largely unaffected and respiration is only slightly depressed in comparison to that noted in suspensions of virulent organisms. It is conceivable that much of the inhibition of multiplication of virulent strains by $\mathbf{M n}^{2+}$ is due to a depression of respiration, since it is hard to conceive that the cation would be involved directly in all of the metabolic systems concerned with nucleic acid and protein synthesis. Rather, it is possible that an inhibition of respiration could result in a suppression of other metabolic systems including nucleic acid and protein syntheses. The inhibition of multiplication of avirulent strains by $\mathrm{Mn}^{2+}$ may be due to a primary effect on nucleic acid synthesis and to a secondary effect on respiration. This is supported by two observations: (a) $\mathrm{Mn}^{2+}$ inhibits nucleic acid synthesis to a much greater extent in avirulent than in virulent suspensions, while respiration in avirulent strains is not affected nearly as much as nucleic acid synthesis; $(b)$ protein synthesis is largely unaffected in avirulent suspensions.

The specific sites of inhibition of respiration and nucleic acid synthesis by $\mathbf{M n}^{2+}$ are unknown. $\mathrm{Mn}^{2+}$ is known to be involved in respiratory processes (Ochoa \& Weisz-Tabori, 1948), but the effects are stimulatory, rather than inhibitory as with streptococci.

In certain respects the effects of supplement-1 on the virulence of streptococci in mice differ from the results obtained with pneumococci (Firshein \& Braun, 1958) and staphylococci (McKee \& Braun, 1962). Both the LD50 and ET 50 values are decreased in the latter two species by supplement-1; but with streptococci, only the ET50 is decreased, the LD50 remaining about the same in controls and supplements. The reason for this is unknown. A point may be made about the possible contribution of DNA degradation products in the outcome of an infection by Gram- 
positive pathogenic cocci. It is conceivable that the occurrence, in vivo, of compounds such as the degradation products might enhance the multiplication of the infecting organisms in susceptible hosts and thus contribute to the pathological effect. Whether these compounds may occur naturally in vivo, or may occur as a result of cellular necrosis during an infection, is still largely unknown. Tillett, Sherry \& Christensen (1948) found that deoxyribonucleases produced by virulent streptococci were effective in hydrolysing deoxyribonucleoprotein from necrotic cells in vivo. However, no correlation was made between the occurrence of the DNA degradation products and multiplication of streptococci in vivo. Although effects of $\mathbf{M n}^{2+}$ on virulence were not studied, the cation has been found to contribute significantly to virulence of pneumococci in mice by stimulating the multiplication of virulent strains in vivo (Hitchings \& Falco, 1946; Firshein, 1962). Thus, by analogy, it may be that $\mathrm{Mn}^{2+}$ will exert a deleterious effect on streptococcal virulence. Studies are under way to examine this possibility.

$\mathrm{Ca}^{2+}$ can antagonize the effects of $\mathrm{Mn}^{2+}$ whether such effects are inhibitory in the case of streptococci, or stimulatory in the case of pneumococci (Firshein, 1962); such interactions have been observed by other investigators. Fry (1955) reported that glutamine synthesis in cultures of staphylococci was activated by $\mathbf{M n}^{2+}$ and was annulled by $\mathrm{Ca}^{2+}$. Gerloffe \& Folke (1957) noted that toxic concentrations of $\mathrm{Mn}^{2+}$ for certain algae in lakes could be rendered less deleterious by addition of $\mathrm{Ca}^{2+}$. The wide variety of environmental conditions under which this interaction can exist suggests that there is a competitive relationship between the two cations, but the nature of this competition, at least in streptococci, is unknown.

The helpful criticism of Dr W. Braun in preparing the manuscript is gratefully acknowledged. The investigation was supported by a grant from the U.S. Public Health Service, CA-06343-02.

\section{REFERENCES}

Brody, S. (1953). A spectrophotometric study on the desoxypentose nucleic acid cysteine reaction. Acta chem. scand. 7, 502.

Drury, A. F. (1948). Identification and estimation of pentose in the presence of glucose. Arch. Biochem. 19, 455.

Firshein, W. $(1961 a)$. Effects of deoxyribonucleic acid products on deoxyribonucleic acid synthesis of virulent and avirulent pneumococci. J. Bact. 82, 169.

Firshein, W. (1961 b). Effects of deoxyribonucleic acid products on respiration of virulent and avirulent pneumococci. J. Bact. 82, 181.

Frrshein, W. (1962). Effect of manganese and enzymatic deoxyribonucleic acid digests on population changes and respiration of pneumococci. J. Bact. 84, 478 .

Firshein, W. \& Braun, W. (1958). On the nature of the selective effects of deoxyribonucleic acid digests upon pneumococci of different virulence. Proc. nat. Acad. Sci., Wash. 44, 918.

Firshern, W. \& Braun, W. (1960). Effects of enzymatic deoxyribonucleic acid digests on population changes and deoxyribonucleic acid synthesis of pneumococci. J. Bact. 79, 246.

Firshein, W. \& Zimmerman, E. M. (1964). Differential toxicity of manganese for virulent and avirulent group A streptococci. J. gen. Microbiol. 36, 249.

Foley, M. J., Smith, M. R. \& Wood, W. B. (1959). Studies on the pathogenicity of Group A streptococci. I. Its relation to surface phagocytosis. J. exp. Med. 110, 603.

Fry, B. A. (1955). Glutamine synthesis by Micrococcus pyogenes var. aureus. Biochem. J. 59, 579 . 
Gerloffe, G. C. \& Folke, S. (1957). Availability of iron and manganese in southern Wisconsin lakes for growth of Microcystis aeruginosa. Ecology, 38, 551.

Hrtchings, G. H. \& Falco, E. A. (1946). Effect of nutrition on susceptibility of mice to pneumococcal infection. Proc. Soc. Exp. Biol., N.Y. 61, 54.

Kay, E. R. M., Simmons, N. S. \& Dounce, A. L. (1952). An improved preparation of sodium desoxyribonucleate. J. Amer. chem. Soc. 74, 1724.

Litchfield, J. T. (1949). A method for the rapid graphic solution of time percent curves. J. Pharm. 97, 399.

Lowry, O. H., Rosebrough, N. J., Farr, A. L. \& Randall, R. J. (1951). Protein measurement with the Folin phenol reagent. J. biol. Chem. 193, 265.

Marmur, J. \& Hotchkiss, R. D. (1955). Mannitol metabolism, a transferable property of pneumococcus. J. biol. Chem. 214, 383.

McKeE, J. J. \& BraUn, W. (1962). Effects of enzymatic digests of DNA on staphylococci. Proc. Soc. exp. Biol., N.Y. 109, 166.

Ochoa, S. \& Weisz-Tabori, E. (1948). Biosynthesis of tricarboxylic acids by $\mathrm{CO}_{2}$ fixation. II. Oxalosuccinic carboxylase. J. biol. Chem. 174, 123.

Ramsey, H. H. \& Wilson, T. E. (1957). Growth inhibition of Micrococcus pyogenes by manganese. Antonie van Leeuwenhoek, 23, 226.

Tillett, W. S., Sherry, S. \& Christensen, L. R. (1948). Streptococcal deoxyribonuclease: significance in lysis of purulent exudates and production by strains of hemolytic streptococci. Proc. Soc. exp. Biol., N.Y. 68, 184.

Wiley, G. G. \& Wilson, A. T. (1961). The occurrence of two M antigens in certain group A streptococci related to type 14. J. exp. Med. 113, 451. 